\title{
Bide partikula: eduki doxastikoa eta ebidentziala
}

\author{
Kepa Korta eta LarRaitz ZUBeLdia ${ }^{1}$
}

ILCLI (UPV-EHU)

\section{(The Basque particle bide: doxastic and evidential content)}

DOI: $10.1387 /$ gogoa.17255

\begin{abstract}
Two kinds of meanings are usually attributed to the Basque particle bide. On the one hand, it is said to indicate the indirect nature of the speaker's evidence for the truth of the proposition at issue. According to this view, it would be a sort of inferential particle. On the other hand, bide has been associated to the expression of a certain degree of belief or certainty on the truth of the proposition. This twofold dimension of bide parallels some features of the meaning and use of another Basque particle -omen. Their morpho-syntactic behaviour, for instance, is practically identical, and their semantics and pragmatics calls for a close comparison. Then, taking as a basis our independent conclusions about omen, we examine the similarities and differences between both particles. They both point to the indirect nature of the evidence the speaker has for the assertion. But we detect two main differences. First, bide encodes an epistemic or doxastic dimension that is not present in the semantic meaning of omen. Second, bide can be taken to be an illocutionary force indicator not contributing to the truth-conditions of the utterance, whereas omen cannot.
\end{abstract}

Keywords: particle, evidential, doxastic, conversational implicature, illocutionary force indicator.

\footnotetext{
1 Artikulu honetako ideiak honako kongresu hauetan aurkeztu ditugu aurrez: International Conference on Evidentiality and Modality in European Languages 2014 (Madril, Espainia) eta 7th International Conference on Intercultural Pragmatics and Communication - INPRA 2016 (Split, Kroazia). Eskerrak eman nahi dizkiegu hango entzuleei, eta bereziki Bert Cornillie, Marta Carretero, Karlos Cid-Abasolo, Ilse Depraetere, Galia Hirsch, Juana Marín-Arrese, Vittorio Tantucci eta Björn Wiemerri. Baita gure lankide Eros Corazza, María de Ponte eta Joana Garmendiari ere, egindako oharrengatik. Ingelesezko aurreko bertsio bat Belgian Journal of Linguisticsen ale berezi batean argitaratu zen (Korta \& Zubeldia 2015). Lan honek proiektu banaren laguntza izan du: Eusko Jaurlaritzarena da bata (IT780-13) eta Espainiako Ekonomia eta Lehiakortasun Ministerioarena bestea (MINECO/FEDER FFI2015-63719-P).
} 


\section{Sarrera}

Bi ezaugarrirekin lotu izan da bide partikularen esanahia literaturan. Egile batzuek hiztunak berak adierazitako proposizioaren egiaren alde duen ebidentziaren edo frogaren zeharkako izaerarekin lotzen dute. Beste batzuek, berriz, haren ezaugarri doxastikoa (ziurtasun maila altua / probabilitatea) azpimarratzen dute, argudiatuz bide erabiltzen dela hiztunak ziurtasun maila altua baina ez erabatekoa duenean proposizioaren egiari buruz. Hain zuzen, ezaugarri horiek berak lotu ohi zaizkio omen berri emateko partikulari ere. Korta \& Zubeldian (2014) arrazoitu genuen omenen kasuan izaera desberdina dutela bi ezaugarri horiek: ezaugarri ebidentziala (informazio-iturriari dagokiona) semantikoa da; doxastikoa (uste izateari dagokiona), berriz, pragmatikoa. Lan honetan, aztertzen dugu banaketa bera egin ote litekeen bideri dagokion bezainbatean. Helburu hori dugula, zeharkako elementu ebidentzial gisa sailkatu ohi diren bi partikulak alderatzen ditugu.

Hasteko, omenen azterketaren nondik norakoak laburtzen ditugu, ondorio nagusien berri emanez. (i) Omeni egotzi izan zaion ziurtasunik ezaren edukia ez da haren semantikaren parte, ezpada omendun esaldiaren bidez sortutako elkarrizketa-inplikatura orokortua (hemendik aurrera GCI); ${ }^{2}$ omenek esanahi ebidentziala (berri ematekoa) besterik ez du (2.1 azpiatala). (ii) Omenek esaldiaren proposizio-edukiari egiten dio ekarpena; ez da ilokuzio-indarraren adierazlea (2.2 azpiatala).

Ondoren, bideren azterketa dakargu. Lehenbizi, haren ezaugarri morfosintaktiko nagusiak biltzen ditugu; omenen tankerakoak dira (3.1 azpiatala). Segidan, batetik, haren esanahi ebidentziala (inferentziala) hartzen dugu kontuan -begiratu batean iradoki lezake balitekeela bide omenen hiperonimoa izatea- (3.2 azpiatala); bestetik, haren esanahi doxastikoa (3.3 azpiatala). Omenek eta bidek zenbait ezaugarri dituzte batean. Gertuagotik begiratuz gero, ordea, argi geratzen da badituztela bi desberdintasun nagusi, behinik behin: elementu doxastikoaren izaerari dagokiona bata eta proposizio-edukiari egindako balizko ekarpenari dagokiona bestea. Batetik, omenen kasuan, izaera pragmatikoa du ezaugarri doxastikoak; bideren kasuan, aldiz, semantikoa da. Gainera, desberdina da partikula bakoitzak hartzen duen eremu doxastikoa: omenek eremu osoa hartzen du; biderena, ostera, mugatuagoa da (4.1 azpiatala). Bestetik, aldea dute esaldiaren egibaldintzei egiten dieten balizko ekarpenean ere: omenek ekarpena egiten dio proposizio-edukiari; bidek ez, ilokuzio-indarraren adierazlea baita (4.2 azpiatala). Bukatzeko, ondorio nagusiak atera, eta aurrera-begirakoak zerrendatzen ditugu.

\footnotetext{
2 Ingelesezko GCI laburdura erabiltzen da literatura orokorrean, generalized conversational implicature delakoari dagokiona, eta horixe baliatuko dugu hemen ere, nahasketarik ez sortzeko.
} 


\section{Omen}

Hasteko, ikus ditzagun omenen esanahia eta edukiak aztertzetik ateratako ondorio nagusiak.

\subsection{Omen eta ziurtasunik eza}

(1) Euria ari omen du.

Euskal hizkuntzalaritzan, uste orokorra da (1)en tankerako omendun esaldia egiten duen hiztunak, informazio-iturria adierazteaz gain (alegia, besteren batengandik jasotako informazioa dakarrela), adierazten duela ez dagoela ziur euria ari duen edo ez. ${ }^{3}$ Aitzitik, aurreko lan batzuetan argudiatu dugu (ikus Korta \& Zubeldia 2014 eta Zubeldia 2015) omeni lotzen zaion ziurtasunik eza ez dela omendun perpausaren esanahiaren parte, baizik eta esaldiaren eduki pragmatikoari dagokiola, betiere halakorik badenean; elkarrizketa-inplikatura orokortua (GCI) litzateke, zehazkiago. Hainbat argudioren emaitzak darabiltzagu ondorio hori ateratzeko: (a) corpusetako adibideak, (b) Griceren ezabagarritasun-testa, (c) Griceren bereizezintasunaren testa eta (d) omenek GCItzat hartu ohi diren beste fenomeno batzuekin duen antzekotasuna.

Omen erabiliz, ziurtasunik eza inplikatzen du batzuetan hiztunak, baina ez beti. Aski da adibideei erreparatzea konturatzeko sarritan ekarritako proposizioaren gainean erabateko ziurtasuna adierazten duela hiztunak. Hortaz, ziurtasunik eza ezin izan daiteke omendun perpausaren esanahiaren parte. Ezta omendun esaldiaren bidez esplizituki esandakoaren parte ere; izan ere, Griceren (1967a, b) ezabagarritasun-testak erakusten du ezabagarria dela ziurgabetasuna. Beraz, edo aberastutako esandakoaren (edo esplikaturaren) parte izan beharra dauka, edo inplikatura.

Hain zuzen, argudiatu dugu GCIa dela. ${ }^{4}$ Omendun perpausaren esaldi batetik inferitzen edo ondorioztatzen da, orokorrean, testuinguru zehatzik gogoan izan gabe; izan ere, omendun esaldia egitean, hiztunak adierazten du besteren batengandik jasotako informazioaren berri ematen ari dela. Ziurtasunik eza ondorioztatzen da emantzat joz hiztuna kooperazio-printzipioa eta kalitatearen bigarren maxima ( «Ez esan hura zeinarentzat ez duzun ebidentzia/froga egokirik») betetzen ari dela (Grice 1967a, 46 or.). Gero, egoera jakinetan, baliteke ziurtasunik eza presente izatea edo ez, eta ziurtasuna ere aditzera eman liteke inolako kontraesanik sortu gabe.

\footnotetext{
3 Ikus, bereziki, duen eraginarengatik, Euskaltzaindia 1987.

4 Antzeko proposamenak egin dituzte Wiemer eta Sockak (2010) poloniera eta alemanierako berri emateko adberbioen kasuan, Fallerrek (2012) cuzco kitxuako eta alemaneko berri emateko ebidentzialentzat eta Wiemer eta Kampfek (2012) bulgarierako markatzaile ebidentzialak aztertzeko.
} 
Horrez gain, ziurtasunik ezaren edukia bereizezina da, ziurtasunik eza gorde egingo bailitzateke gauza bera beste eraren batean esatean; adibidez, omendun esaldia egin partez esandun esaldia egitean. Azkenik, omenen ziurtasunik ezaren edukia Gricek uste izanekin lotutako ezagutzarik ezaz ematen duen azalpenarekin esplika daiteke, bi egituren antzekotasuna dela eta. Hain zuzen, parekotasun horrek ere proposatu dugun azterketaren alde egiten du. ${ }^{5}$

\subsection{Omenen ekarpena}

Ziurtasunik eza omendun perpausaren esanahitik kanpo utzita, argudiatu dugu elementu ebidentziala (berri ematekoa) soilik dela omendun perpausaren esanahia; alegia, ekarritako proposizioa hiztuna ez den besteren batek esana dela. Esanahi ebidentzial horixe da omenek esaldiaren proposizio-edukiari egiten dion ekarpena. Beraz, ez da ilokuzio-indarraren adierazlea; desberdina da omenik gabeko esaldi batek eta omendun esaldi batek baiezten dutena. Bi froga nagusi darabiltzagu hori ondorioztatzeko. Batetik, onartze/ ez-onartzearen testean oinarrituta egindako esperimentuen emaitzek erakusten dute omendun esaldi bat zuzenean zalantzan jartzen denean, parte-hartzaileek onartzen dutela eduki ebidentziala ukatzea, ekarritako proposizioa ukatzea onartzeaz gain. Bestetik, eragin-eremuaren testak dio omendun esaldiaren eduki ebidentzialak har dezakeela zenbait operatzaileren baitako eragin-eremu estua; zehazkiago, perpausaren (kanpoko) ukazioaren baitakoa, esan nahiz erantzun gisako komunikazio-predikatuen baitakoa eta kontuan hartu moduko ezagutza-predikatuen baitakoa.

Horrez gain, kontraesana sortzen da omendun esaldiaren eduki ebidentziala ezabatzen saiatuz gero. Hain zuzen, omenek proposizio-edukiari ekarpena egiten diola esateko beste argumentu bat da hori.

Ondorio horiexek atera ditugu omeni dagokionez lehenagoko lanetan (ikus, Korta \& Zubeldia 2014 xehetasun gehiagorako). Orain, lan honen helburua da ondorio horiek bide partikularen kasuarekin alderatzea, eta ikustea partikula horren jokaera semantikoa eta pragmatikoa omenenaren antzekoa ote den.

\section{Bide}

Bideren jokabide semantikoa eta pragmatikoa aztertzen hasi aurretik, haren ezaugarri morfosintaktiko nagusien berri emango dugu.

\footnotetext{
5 Ikus Grice (1967b/1989) eta Levinson (1983) uste izanen kasurako; aldiz, beste kasu batzuetarako (disjuntzioa, konjuntzioa, etab.) ikus Grice (1981) eta Levinson (2000).
} 


\subsection{Bideren ezaugarri morfosintaktikoak}

Bideren sintaxia omenenaren oso antzekoa da. Aditz jokatuekin agertu ohi da, aditzaren gunean. Baiezko perpausetan, aditzaren aurre-aurretik joaten da aditz trinkoekin ((2) adibidea); aditz perifrastikoekin, berriz, aditz nagusiaren eta laguntzailearen artean ((3)).

(2) Eguraldi ona bide dator.

(3) Eguraldi ona egingo bide $d u$.

Ezezko perpausetan, ostera, aditz trinkoekin aditzaren aurre-aurretik ageri da berebat (4); aldiz, aditz perifrastikoekin aditz laguntzailearen aurrean, hura aditz nagusiaren aurrera mugituta dela (5).

(4) Ez bide dator eguraldi onik.

(5) Ez bide $d u$ eguraldi ona egingo.

Horrez gain, adierazpen-perpausetan bakarrik agertu ohi da, omen nola; bai perpaus nagusietan, bai mendekoetan.

Esan gabe doa omen oso ohikoa dela ahozko nahiz idatzizko erregistroan; bide, berriz, ez da hain maiz erabiltzen euskara mintzatuan (ekialdeko euskalkietan darabilte, baina ez zubereraz, itxura denez), eta, idatzizkoan erabiltzen den arren, ez da omen bezain ohikoa. Bestelako hizkuntz elementu batzuk darabiltzagu askotan euskal hiztunok bideren lekuan; esate baterako, geroaldiko adizkiak ((6) adibidea), 'behar ukan' aditza ((7) adibidea), iduri du, badirudi ((8) adibidea), partizipioa + izan + -go + aditz laguntzailea ((9) adibidea) edo adberbio/adizlagunak ((10)-(11) adibideak).

(6) Etxera etorriko zen.

(7) Etxeratua behar du.

(8) Badirudi etxera etorri dela.

(9) Etxera etorri izango da.

(10) Etxera etorri da nonbait.

(11) Etxera etorri da sobrare.

\section{2. (Zeharkako) esanahi ebidentziala}

Badirudi hainbat ezaugarri edo elementu berdin dituztela bideren semantikak eta omenen semantikak. Lehenbiziko begiratuan iduri du bata bestearen ordez erabil litezkeela, trukagarriak direla, honako esaldi hauetan bezala:

(12) Asko mugitzen omen naiz lotan nagoela.

(13) Asko mugitzen bide naiz lotan nagoela. ${ }^{6}$

\footnotetext{
${ }^{6}$ Sartreren La nauséeren euskarazko itzulpenetik egokitutako adibidea (1938 [2003], 111 or.). Ereduzko Prosa Gaur corpusa erabili dugu lan honetan, Euskal Herriko Unibertsitatekoa.
} 
Begi-bistako arrazoiak direla eta, hiztunak, lo dagoela, ezin duenez zuzenean hauteman bere jarrera, proposizioarentzat (asko mugitzen dela lo dagoela) duen zeharkako ebidentzia adierazten du. Intuitiboki, (12) esaldia eginez, hiztunak baiesten du besteren batek esana diola asko mugitzen dela lo dagoenean. (13) esaldia eginez, berriz, bere ebidentziaren zeharkakotasuna adieraziko luke; hau da, baliteke proposizioa ondorioztatu izana bere oheak goizero izaten duen itxura ikusita, edo baliteke, baita ere, besteren batek esan izana hori berari, (12)n bezala. Bada era horretako adibide gehiago corpusean, non bide erabiltzen den hiztunak ahozko ebidentzia edo froga duenean bere inferentziarentzat. ${ }^{7}$ Ikus, esaterako, honako esaldi hau:

(14) Gauez, ostera bai, agertzen bide dira itsaspekoak azalera, Gregoryk kontatuko duen legez. (Jimenez 2003, 187 or.)

Hain zuzen, adibide horietan bide eta omen elkarren ordez erabili ahal izateak iradokitzen du hiztunaren baiespenarentzako ebidentzia edo frogaren zeharkako izaera adierazten duten ebidentzialtzat har litezkeela bi partikulak. Zehatzago esanda, omen partikulak adierazten du, esaldi batean (non erabilitako perpausa den $S^{8}$ perpausa gehi omen partikula), hiztunak ekarritako $p$ proposizioarentzat (Sren esaldiaren bidez adierazitako proposizioarentzat) duen ebidentziaren hizkuntzazko izaera; bide partikulak, berriz, seinalatzen du hiztunak proposizio horrentzako duen ebidentziaren zeharkako izaera. Edo, beste hitz batzuetan esanda, omendun esaldiaren hiztunak (15) baiesten du; bidedun esaldiarenak, aldiz, (16).

(15) Esana da $p$.

(16) Zeharkako ebidentzia dut prentzat.

Hori bat dator bide inferentziazko partikula (ebidentziala) den ideiarekin. Novia de Salcedo $(1887,307$ or.) hiztegigileak, esaterako, horri egiten dio erreferentzia: «adizki konplexuetan, gauzatutako balizko ekintza baten baliokidea da, eta, erantzunean atzeratuta, dirudienezena». ${ }^{9}$ Baita de Rijkek (2008, 162 or.) ere, esaten baitu bidek «adierazten duela ezagunak zaizkion gertaera batzuek eraman dutela hiztuna bere baiezpenaren egia ondorioztatzera». ${ }^{10}$ Orobat Boyek (2012, 82 or.), esanez «... bideren esanahia inferentziazko justi-

\footnotetext{
7 Badirudi zenbaitetan beste norbaitek kontatua izaten dela inferentziarentzat oinarria (alderatu Marín-Arresek (2015) proposatzen duen «berri ematean oinarritutako inferentzia»rekin), eta ez hautemate edo arrazoitze hutsa.

8 Ohikoa denez, ingelesezko sentenceri dagokion $S$ gordeko dugu ulergarritasunaren mesedetan, irakurlea aldiko $P$ (perpausa) eta $p$ (proposizioa) bereizten ibili beharrik gabe.

9 ... interpuesta en las voces compuestas, equivale á un supuesto de hecho realizado, y pospuesta en la contestación á, parece... Aipuaren jatorrizko idazkera gorde dugu.

${ }^{10}$ [bide] signals that certain facts known to the speaker lead him to infer the truth of his statement.
} 


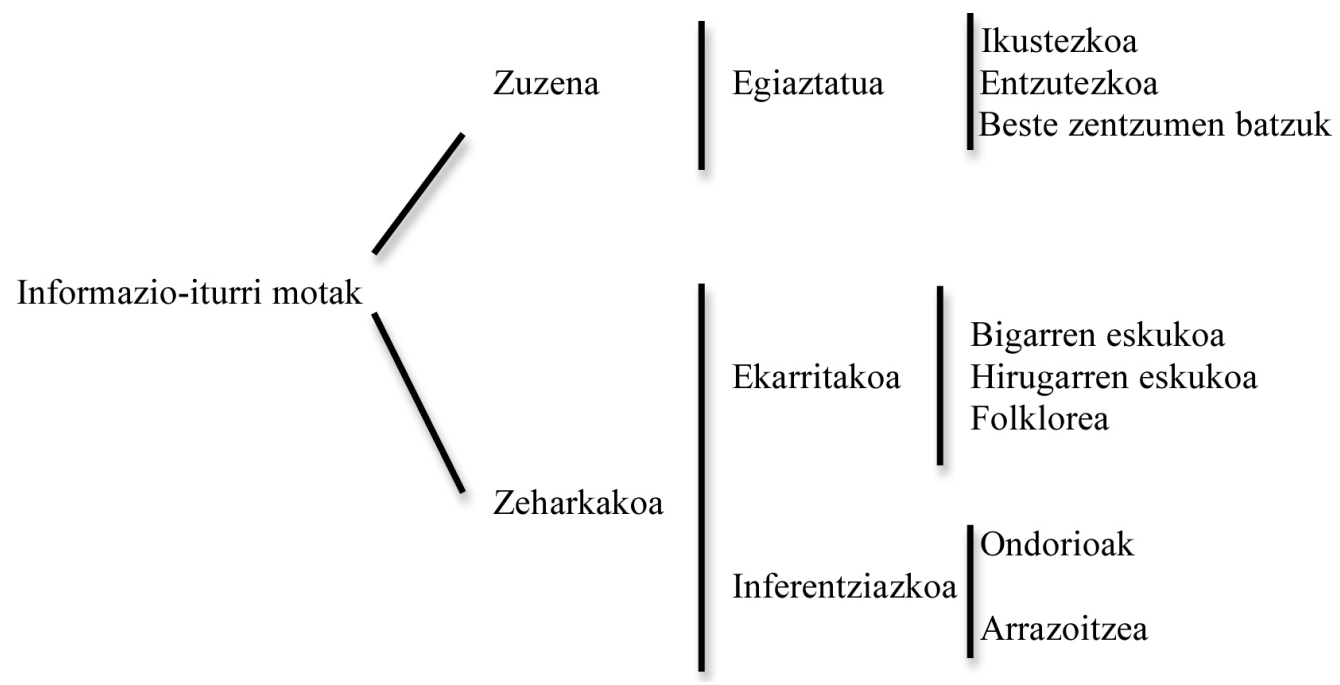

1. irudia

Willetten (1998) informazio-iturri moten sailkapena

fikazioaren arabera deskriba liteke[ela]» ${ }^{11}$ (ikus, berebat, Alcázar 2009 eta Jendraschek 2003). Horri jarraiki, Willetten (1998) sailkapenaren arabera (1. irudia), ebidentzialitate zuzena eta zeharkakoa (edo, Boyeren (2012) terminoa erabiliz, justifikatzea) bereizten baditugu, badirudi bi eratako ebidentzialitatea bereizten duela euskarak azkeneko kategoriaren baitan: hizkuntzaren bidez ekarritako ebidentzia eta beste era bateko zeharkako ebidentzialitatea (2. irudia). Kontua litzateke, beraz, erabakitzea bide omenen hiperonimo tankerakoa den, era guztietako zeharkako ebidentzialitateentzat erabil litekeena - baita hizketaren bidezko berri emateen kasuan ere-, edo bestelako harremanen bat duten bi partikulek. 4.1 azpiatalean eztabaidatuko dugu sakonago auzia, hainbat zalantza adieraziz; izan ere, ikusiko dugu, partikula bat ala bestea erabili, informazio bat irabazten dela, eta beste bat galdu. Horrek ezbaian jartzen du bi partikulak baliokideak edo bata bestearen hiperonimo/ hiponimo izatea.

Horraino, beraz, bideri egotzitako esanahi ebidentzialari buruz oraingoz esan dezakeguna. Segidan, bideri egotzitako bigarren esanahiari helduko diogu; esanahi epistemikoari (ezagutzari dagokionari) edo, egokiago esanda seguru asko, doxastikoari (usteei dagokienari).

11 ... the meaning of bide may be described in terms of inferential justification. 


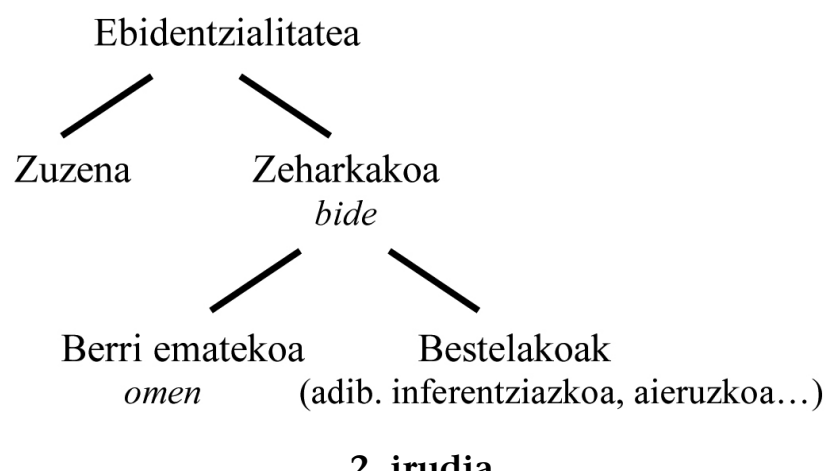

Bide eta omen zeharkako partikula ebidentzial gisa

\subsection{Esanahi doxastikoa}

Beste egile batzuek beste ezaugarri batekin lotzen dute bideren esanahia: ziurtasunaren edo ziurtasunik ezaren neurriren bat adieraztearekin. Omeni ere egotzi izan zaio eduki hori, lehen ikusi bezala. Esaterako, Euskaltzaindiak bidez dioena bat dator omenez dioenarekin: «Esaten dugunari ziurtasun oso-osoa ematen ez badiogu ere, egiantz handia bederen eskaintzen diogula adierazteko bide partikula dugu.» (Euskaltzaindia 1987, 502 or.). ${ }^{12}$

Gehiago zehaztuz, bideren alde doxastikoaren ezaugarri jakin bati egiten diote erreferentzia egile horiek. Emantzat jota $p S$ perpausak adierazitako proposizioa dela, bidedun perpausa (hau da, $S$ gehi bide) darabilen hiztunak adierazten du egiantzekotasun edo sinesgarritasun handia egozten diola pri; alegia, $p$ oso litekeena dela, baina ez erabat ziurra.

(13) adibidea hartuko dugu berriro ((17) gisa dakargu hemen). Badirudi esaldi hori eman litekeela ez (18) gisa bakarrik, baizik eta baita (19) gisa ere.

(17) Asko mugitzen bide naiz lotan nagoela.

(18) Zeharkako froga edo seinalea dut asko mugitzen naizela lotan nagoela.

(19) Oso litekeena da baina ez erabat ziurra ni asko mugitzea lotan nagoela.

Eta gauza bera esan liteke honako adibide hauez ere:

(20) Bai, uda bide zen, garai epelen bat behintzat. (Jimenez 2004, 128 or.)

(21) Sakona bide zen haren loa. (Mendiguren 2002, 114 or.)

(22) Jon, ipurdia hara eta hona astintzen, dantzan ari bide zen. (Iturriaga 1999, 226 or.)

12 Ikus, halaber, van Eys 1873, Orpustan 1993 eta Elhuyar-Elkar 1994, beste batzuen artean. 
Adibide horietan guztietan, badirudi bide eman litekeela hala zeharkako ebidentzial gisa (adieraziz hiztunak zeharkako ebidentzia duela pren egiarentzat), nola maila doxastikoa adierazten duen partikula gisa (adieraziz hiztunak probabilitate edo gertagarritasun handia egozten diola pri, baina ez erabateko ziurtasuna).

Bideren esanahi bikoitz horrek espero gabeko ondorioa dirudike. Teoriari dagozkion ekonomia-arrazoiei kasu eginez gero, esanahi bat lehentasunezkotzat eta bestea hortik eratorritzat hartzea litzateke egokiena. Omenen kasuan, gogora dezagun, hala argudiatu dugu, haren berri ematearen eta ziurtasunik ezaren ezaugarriak aztertzean: omendun perpausaren esanahia berri emateko hutsa da; omendun esaldiei sarritan egozten zaien ziurtasunik eza, berriz, elementu pragmatikoa (GCIa, hain zuzen). Bideri dagokionez, bi aukera daude norabide hori hartuz gero: (i) zeharkako ebidentziaren ezaugarria bideren esanahi semantikoa da, eta probabilitate handia baina ez erabatekoa adieraztea, aldiz, bidedun esaldiaren elementu pragmatikoa; edo (ii) alderantziz —elementu doxastikoa semantikoa da; ebidentziala, ostera, pragmatikoa-.

Lehenbiziko aukerari jarraituz, esaterako, argudiatuko genuke gertagarritasun handiaren baina ez erabatekoaren balizko GCIa bidedun perpaus baten esalditik ondorioztatu edo inferituko litzatekeela, orokorrean (testuinguru jakinik gogoan izan gabe), omendun esaldiaren kasuan gertatzen den tankeran. Pentsa daiteke hiztunak, bidedun perpaus bat egitean, adierazten duela zeharkako ebidentzia duela, eta, ondorioz, ezin lezakeela baietsi, ziurtasun osoz, ondorioztatutako esaldiaren egia. Inferituko litzateke emantzat joz hiztuna kooperazio-printzipioa eta kualitatearen bigarren elkarrizketa-maxima ( Ez esan ezer zeinarentzat ez duzun nahikoa frogarik») jarraitzen ari dela. Nolanahi ere, GCIa den neurrian, egoera jakinetan, baliteke ziurtasun-neurria hor egotea edo ez. Halako auzietan lagungarri izaten da ezabagarritasuntesta, lagun baitezake ebazten edo erabakitzen dena delako informazioa esaldiaren edukiaren parte den ala inplikatura den. Dena den, guk esku artean dugun kasuan, ez digu laguntzen argitzen zein bidetatik jo beharko litzatekeen. Badirudi ezaugarri doxastikoa ez dela esplizituki ezabagarria. (17) gisako bidedun esaldiaren ondoren «eta/baina ez da inola ere posible» moduko ezer erantsiz gero, esaldi arraroa sortzen da; kontraesan garbia ez esateagatik ((23) adibidea). Baina bigarren aukerari erreparatuta, orobat, iduri du zeharkako ebidentziaren ezaugarria ere ez dela ezabagarria, esaldi arraroa sortzen baita (17) gisako bidedun esaldiaren ondoren «eta/baina ikusi dut» moduko zerbait esanez gero ((24) adibidea).

(23) ?? Asko mugitzen bide naiz lotan nagoela. Baina ez da posible.

(24) ?? Asko mugitzen bide naiz lotan nagoela. Eta ikusi dut.

Ez dugu topatu, ezta ere, testuinguruaren bidez ezabatzearen kasu argirik: badirudi burura litekeen ezein egoeratan dutela bidedun esaldiek euren 
zeharkako ebidentziaren esanahia edo/eta esanahi doxastikoa. Hortaz, beste jarrera edo ikuspegi bat hartu beharko dugu, apika, auzi honetan.

Baliteke $p$ proposizioaren egiarentzako ebidentziaren zuzentasuna/zeharkakotasuna, batetik, eta $p$ egiazkoa delako gure ustearen indarraren neurria, bestetik, txanpon beraren bi aldeak izatea. ${ }^{13}$ Egia esan kidetasun edo harreman sistematikoa dago uste batentzat dugun ebidentzia motaren eta gure ziurtasun-neurriaren artean (ikus, adibidez, Chafe 1986 eta Matlock 1989). Gertaera bat ikusmenaren bidez zuzenean hautemateak gertaeraren baiezpenari buruzko erabateko ziurtasuna dakar normalean. Esan ohi den bezala, «ikustea sinestea da». «Erabat sinestea», erantsiko genioke.

Hori hala balitz, ez luke zentzu handirik bideri lotutako zeharkako ebidentzialitatea eta ziurtasun-neurri altua baina ez erabatekoa bereizteak, batera joango edo agertuko bailirateke beti. Otik 1erako eskalan probabilitateak ezarriz gero, ikus dezakegu 1 (erabateko ziurtasuna pri dagokionez) eta 0 (erabateko ziurtasuna pren ukazioari dagokionez) bat datozela pren egiarentzako (faltsutasunarentzako) ebidentzia zuzentzat hartutako horretan; eta, preseski, kasu horietan da zorigaiztokoa ${ }^{14}$ bide erabiltzea, adibideek erakusten duten bezala.

(25) \#Euria egin bide du, baina ikusi dut nola egin duen.

(26) \#Euria egin bide du, baina ez du egin.

Honainokoa kontuan hartuta atera dezakegun ondorioa da iduri duela bide egokia dela soilik hiztunak $n$ probabilitatea egozten dionean $p$ proposizioari, non $0,5<n<1$ den. Hori bat dator bete-betean hiztunak pren egiarentzako zeharkako ebidentzia duen kasuekin, pren faltsutasunarentzat zeharkako ebidentzia duen kasuei kontrajarrita. Hala, esanahi ebidentziala eta doxastikoa, biak, kodetuko lituzke bidek. ${ }^{15}$ Kide duen eta erreferentziatzat hartu dugun omenekin sakonago alderatzeak, ordea, iradokitzen du bideren

\footnotetext{
13 Alderatu hau van der Auwera \& Plungianen (1988, 86-87 or.) ikuspegiarekin; alegia, inferentziazko ebidentzialitatea eta beharrezkotasun epistemikoa kategoriak gainjartzearenarekin. Ikus, edozein moduz ere, Cornillie (2009) eta Boye (2010), zalantzan jartzen baitute ikuspegi hori. Boyek (2012) epistemikotasuna delako kategoria proposatzen du, zeinak ebidentzialitatea (justifikatze epistemikoa) eta modalitate epistemikoa (sostengu epistemikoa) azpikategoriak hartzen dituen bere baitan.

${ }^{14}$ Halaxe itzuli dugu hizketa-ekintzen teoriako infelicitous terminoa.

15 Antzeko ondorioa ateratzen du Fallerrek (2002) cuzco kitxuako -chá enklitikoa aztergai duela. Haren arabera, ezaugarri ebidentziala eta modala, biak, dira -cháren esanahiaren parte: «-Cháren esanahia ez da ebidentzial hutsa, adieraziz hiztuna arrazoitzez heldu dela bere baiezpenera. Kodetzen du, baita ere, hiztuna ez dagoela \% 100 ziur adierazitako proposizioa egiazkoa dela» [The meaning of -chá is not purely evidential, indicating that the speaker arrived at his or her statement by reasoning, but also encodes that the speaker is less than 100\% certain that the proposition expressed is true] (Faller 2002, 177 or.).
} 
elementu doxastikoak nolabaiteko lehentasuna duela esanahi ebidentzialaren aurretik. Badirudi, bideri dagokion bezainbatean, ez daudela maila berean bi elementuak. Omenen kasuan alderantzizkoa gertatzen da, esanahi ebidentziala du beti-bateko edukia; eta lehentasuna du, beraz. Goazen, bada, bi elementuak polikiago alderatzera, desberdintasunak nabarmentze aldera.

\section{Bide versus omen}

Goian esan dugu, ebidentzial gisa, balitekeela omen bideren hiponimoa izatea, eta, hala, omen erabiltzen den lekuan bide ere erabili ahal izatea (alderantziz ez, ordea, beti). Nolanahi ere, sakonxeago aztertuz gero, bat ohartzen da desberdintasun esanguratsuak dituztela biek. Batetik, ezaugarri doxastikoari dagokionez; bestetik, proposizio-edukiari egindako balizko ekarpenari dagokionez.

\subsection{Elementu doxastikoa}

Hasteko, badute alde nabarmen bat bi partikulek elementu doxastikoari erreparatuz gero. Lehen aurreratu bezala, ohartu gara elementu doxastikoak ez duela inolako lekurik omenen esanahian: $p_{\text {omen }}$ baieztea bateragarria da erabat prekiko zeinahi jarrera doxastikorekin, hasi erabat uste izatetik (1) eta inola ere ez uste izatera (0); halaber, bien arteko ezein uste-neurrirekin. Eremu guztia hartzen du omenek, hiztunak pri probabilitatea egozteari dagokionez. Alegia, hiztunak omen erabil dezake besteren batengandik jasotakoa uste ez duenean, baina baita $p$ erabat uste duenean ere. Hortaz, omendun esaldiei lotzen zaien erabateko ziurtasunik eza ez da omendun perpausen esanahiaren parte, ezpada omendun esaldia eginez sortzen den GCIa. Halaxe erakusten du esplizituki eta testuinguruan ezabagarria izateak, beste gauza batzuen artean (ikus Korta \& Zubeldia 2014, 407-412 or. xehetasun gehiagorako).

Horrez gain, ez da kontraesanik sortzen hiztunak lehenbizi $p_{\text {omen }}$ baieztu eta segidan bere desadostasuna edo halakorik uste ez duela adierazten duenean ((27)n bezala), ezta $p$ ukatzen duenean ere ((28) adibidea).

(27) Euria egin omen du, baina ez dut uste.

(28) Euria egin omen du, baina ez du egin.

Bestelakoak dira kontuak bideren kasuan. Hasteko, badirudi bide ez dela bateragarria hiztunak pren egiaren (edo faltsutasunaren) gaineko erabateko ziurtasuna izatearekin. Horregatik dira zorigaiztokoak aurreko (25) eta (26) esaldiak eta segidako (29). 
(29) \#Euria egin bide du, eta/baina euria egin du.

(30) \#Euria egin bide du, eta/baina ez du egin euririk.

Tankera berean dira zorigaiztoko nonbait adberbiodun esaldiak ((31)-(32)) eta «iraganaren geroaldia» dutenak ((33)-(34)).

(31) \#Euria egin du nonbait, eta/baina euria egin du.

(32) \#Euria egin du nonbait, baina ez du egin.

(33) \#Euria egingo zuen, eta/baina euria egin du.

(34) \#Euria egingo zuen, baina ez du egin. ${ }^{16}$

Hortaz, bideri lotzen zaion erabateko ziurtasunik eza ez da bidedun esaldien GCIa, baizik eta bidedun perpausek, testuinguruez gaindi, duten ezaugarri aldaezina edo beti-bateko edukia; hots, beren esanahiaren parte da. Bidek -omenek ez bezala, hasteko, eskatzen du erabateko ziurtasunik eza (1 baino txikiagoa). Horregatik dira zorigaiztokoak (29) eta (30) esaldiak. Eta, bigarrenik, eskatzen du - kasu honetan ere omenek ez bezala-, ziurtasun-maila handia $(0,5$ etik gorakoa). Horregatik kontraesana sortzen da, esaterako, (35) esaldia eginda.

(35) \#Euria egin bide du, baina ez dut uste.

Beraz, iduri du hiztunak ez duela baliatuko pri dagokion bidedun esaldirik ( $p$ adierazten duen bidedun esaldirik) $p$ proposizioari 0,5eko probabilitatea ematen dionean (alegia, egoera batean non ez duen uste $p$ proposizioa egiazkoa denik, ez faltsua denik). Ezta, esaterako, 0,3ko probabilitatea dagoen kasuetan ere ((35) adibidean bezala); aitzitik, ez- $p$ adierazten duen (36) ren moduko bidedun esaldia egingo luke.

(36) Ez bide du egin euririk.

Eta, berriro ere, badirudi gauza bera gertatzen dela nonbait adberbioarekin eta iraganaren geroaldiarekin.

Laburtuz, hortaz, badirudi omenen eta bideren arteko harremana ez dela hiponimoaren eta hiperonimoaren artekoa, hasieran iradoki bezala. Izan ere, zein partikula erabiltzen den, informazio bat irabazten da, baina beste bat galdu. Omen erabiliz gero, $p$ proposizioarentzako ebidentzia motari buruzko informazioa lortzen da -hizketa versus bestelako zeharkako ebidentzia-,

\footnotetext{
16 Interesgarria da ikustea bestelakoak direla gauzak badirudi aditzarekin, bai baitirudi erabat egokiak direla honako esaldi hauek:

Badirudi euria egin duela, eta euria egin du.

Badirudi euria egin duela, baina ez du egin.
} 
baina hiztunak prekiko duen jarrera doxastikoaren gaineko informazioa galtzen da. Bide erabilita, berriz, alderantzizkoa gertatzen da: hiztunak pri buruz duen uste maila handi baina ez erabatekoaren gaineko informazioa eskuratzen da, baina zeharkako ebidentzia mota jakinaren gainekoa desagertzen - hizketarena- Beste hitz batzuetan esanda, bide erabil daiteke omenen ordez probabilitatea handia baina ez erabatekoa den kasuetan, nahiz eta berri emateko izaeraren esplizitutasuna galtzen den ordainetan. 3. irudiak erakusten du bideren eta omenen arteko aldea ezaugarri doxastikoari dagokionez, $p$ proposizioa kontuan hartuta.

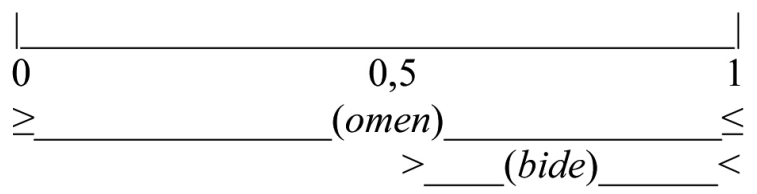

3. irudia

pren egiari buruzko ziurtasuna

Orain arte emantzat jo dugu zeharkako (edo inferentziazko) ebidentzia bat datorrela ziurtasunik ezarekin. Dena dela, baliteke hala ez izatea. Uste dugu, bederik, zeharkakotasuna (edo inferentzialtasuna) eta erabateko ziurtasunik eza ez datozela beti batera. Baliteke batek zerbaiten zeharkako ebidentzia izatea eta erabat ziur egotea hala dela. Baita zuzeneko informazioa izatea baina ziurtasun osorik ez izatea ere. Gaude, hortaz, ez daukatela batera joan beharrik, eta ziurtasunik ezak nolabaiteko lehentasuna duela bideren kasuan. Zereginari dagokionez, ezaugarri doxastikoak nagusitasuna du, behintzat, $b i-$ deren kasuan, omenen kasuan ez bezala.

Segidan, bidek eta omenek duten beste desberdintasun bat hartuko dugu aztergai: esaldiak adierazitako proposizioari egiten dioten ekarpena edo ekarpenik eza.

\subsection{Bide ilokuzio-indarraren adierazle gisa}

Elementu ebidentzialen eta epistemikoen (edo doxastikoen) esanahia eta erabilera aztertzean bada gai garrantzitsu bat: euren esanahiak delako elementua duen esaldiaren proposizio-edukiari ekarpenik egiten ote dion ala ez. Hainbat irizpide proposatu izan dira auzia aztertzeko, tartean lehen aipatu ditugun onartze/ez-onartzearen testa eta eragin-eremuaren printzipioa (ikus, beste batzuen artean, Faller 2006, Matthewson eta beste 2007, Murray 2010 eta Matthewson 2012 lehenbizikoarentzat, eta Faller 2002, Matthewson eta beste 2007, McCready \& Ogata 2007, Sauerland \& Schenner 2007, Schenner 2008, eta Waldie eta beste 2009 bigarrenarentzat). 
Omeni dagokionez, hasieran esan bezala, gaude esaldiaren egibaldintzei egiten diela ekarpena argi eta garbi. Hala, egoera berean, hiztunak, $S$ perpausaren esaldia egin edo $S_{\text {omen }}$ perpausaren esaldia egin, proposizio desberdina baietsiko du. Joanak «Euria ari du» esaldia egiten badu Anoetan gaur, baiesten du euria ari duela Anoetan gaur; alegia, proposizio bat egiazkoa dena baldin eta bakarrik baldin euria ari badu Anoetan gaur. «Euria ari omen du» esaldia egiten badu, aldiz, baiesten du bera ez den besteren batek baieztua dela euria ari duela Anoetan gaur; hau da, proposizio bat egiazkoa dena baldin eta bakarrik baldin bera ez den besteren batek baieztua bada euria ari duela Anoetan gaur. ${ }^{17}$

Hizketa-ekintzen teoriaren baitan, esan liteke, beraz, perpaus bati omen eransteak ez diola eragiten esaldiaren ilokuzio-indarrari (baiespenak baiespena izaten jarraitzen baitu), baizik eta proposizio-edukia aldatzen duela. Oro har, Sren esaldi bat eta $S_{\text {omen }}$ en esaldi bat alderatzen baditugu, hainbat antzekotasun eta desberdintasun atzemango ditugu ilokuzio-indarraren hainbat ezaugarriri dagokienez; hain zuzen, egokitze-norabideari, zintzotasun-baldintzei eta asetze-baldintzei dagokienez (ikus 1. taula).

\section{1. taula}

Sren eta $S_{o m e n}$ en ilokuzio-indarren hiru osagai alderatuta

\begin{tabular}{c|ll}
\hline & \multicolumn{1}{|c}{$S$ (Euria ari du) } & \multicolumn{1}{c}{$S_{\text {omen }}$ (Euria ari omen du) } \\
\hline Egokitze-norabidea & Hitzetatik mundura & Hitzetatik mundura \\
\hline Zintzotasun-baldintzak & $\begin{array}{l}\text { Hiztunak } p \text { (euria ari du } \\
\text { gaur Anoetan) uste du }\end{array}$ & $\begin{array}{l}\text { Hiztunak uste du } p \text { (euria } \\
\text { ari du gaur Anoetan) bera } \\
\text { ez den besteren batek baiez- } \\
\text { tua dela }\end{array}$ \\
\hline Asetze-baldintzak & $\begin{array}{l}\text { Hizketa-ekintza asetzen da } \\
\text { baldin eta bakarrik baldin } \\
p \text { egiazkoa bada (euria ari } \\
\text { badu gaur Anoetan) }\end{array}$ & $\begin{array}{l}\text { Hizketa-ekintza asetzen da } \\
\text { baldin eta bakarrik baldin } p \\
\text { (euria ari du gaur Anoetan) } \\
\text { hiztuna ez den besteren ba- } \\
\text { tek baieztua bada }\end{array}$ \\
\hline
\end{tabular}

Aldea, beraz, ez dago ilokuzio-indarrean, bi esaldiak baiespenak baitira (nahiz eta baiespen desberdinak izan). Hain zuzen, omenek esaldiaren propo-

17 Esaldi batek omen duenean, adierazitako proposizioak iturri mugatuagoa izan dezake. Zehatzago esateko, omendun esaldietan ez dago informazioaren iturria zehaztu beharrik adierazitako proposizioa mugatzeko. Dena den, zehatz daiteke, testuinguruko informazioa kontuan hartuta. Nolanahi ere, ez ditugu kontuan hartuko xehetasun horiek lan honetan. Ikus Korta \& Zubeldia (2014) eta Zubeldia (2013) xehetasun gehiagorako. 
sizio-edukia —munduak nolakoa izan behar duen esaldia egiazkoa izateko-, zintzotasun-baldintzak —nolakoa izan behar duen hiztunaren gogo-egoerak bere esaldia zintzoa izan dadin - eta asetze-baldintzak —zein baldintzatan den egiazko proposizio-edukia- aldarazten ditu. ${ }^{18}$

Horrekin alderatuta, argudiatzen dugu ez dela halako desberdintasunik Sren esaldi baten eta $S_{\text {bide }}$ ren esaldi baten artean. Joanak, aurreko egoera berean, «Euria ari bide du» esaldia egiten badu, ez dira aldatzen aipatu ditugun ilokuzio-indarraren hiru osagaiak; esan nahi baita, bere esaldiaren egokitzenorabidea, zintzotasun-baldintzak eta asetze-baldintzak (ikus 2. taula).

\section{2. taula}

Sren eta $S_{\text {bide }}$ ren ilokuzio-indarren hiru osagai alderatuta

\begin{tabular}{c|ll}
\hline & \multicolumn{1}{|c}{$S$ (Euria ari du) } & \multicolumn{1}{c}{$S_{\text {bide }}$ (Euria ari bide du) } \\
\hline Egokitze-norabidea & Hitzetatik mundura & Hitzetatik mundura \\
\hline Zintzotasun-baldintzak & $\begin{array}{l}\text { Hiztunak } p \text { (euria ari du } \\
\text { gaur Anoetan) uste du }\end{array}$ & $\begin{array}{l}\text { Hiztunak } p \text { (euria ari du } \\
\text { gaur Anoetan) uste du }\end{array}$ \\
\hline Asetze-baldintzak & $\begin{array}{l}\text { Hizketa-ekintza asetzen da } \\
\text { baldin eta bakarrik baldin } p \\
\text { (euria ari du gaur Anoetan) } \\
\text { egiazkoa bada }\end{array}$ & $\begin{array}{l}\text { Hizketa-ekintza asetzen da } \\
\text { baldin eta bakarrik baldin } p \\
\text { (euria ari du gaur Anoetan) } \\
\text { egiazkoa bada }\end{array}$ \\
\hline
\end{tabular}

Bidedun esaldiak baiespena dirudi — partikularik gabeko esaldiaren antzera-, hitzetatik mundurako egokitze-norabidea duena, proposizio-eduki bera uste izatea zintzotasun-baldintza gisa eta proposizio-eduki bera egiazkoa izatea asetze-baldintza gisa. Eta gauza bera baiesten dute, gainera, Sren eta $S_{\text {bide }}$ ren esaldiek: $p$, alegia. Desberdintasun bakarra legoke, agidanean: zintzotasun-baldintzaren ezaugarri den ustearen sendotasunaren neurrian. Ilokuzio-xede bera lukete (baiespenak lirateke), baina aldea sendotasunaren neurrian. Searle \& Vandervekenek (1985, 15 or.) eta Vandervekenek (1990, 119-121 or.) hizketa-ekintzaren ilokuzio-indarraren osagaitzat dute sendotasunaren neurria, eta badirudi bidek mugatzen duela sendotasunaren neurriak 0,5 eta 1 bitartekoa izan behar duela $(0,5$ baino handiagoa eta 1 baino txikiagoa). Beraz, ondorioztatzen dugu ilokuzio-indarraren adierazlea dela bide, ilokuzio-indarraren sendotasun-neurriari egiten diola ekarpena, eta ez esaldiaren proposizio-edukiari.

\footnotetext{
18 Ikus Faller (2002, 189-204 or.) beste ondorio baterako. Argudiatzen du cuzco kitxuako -si berri ematekoak —omenen tankerakoa da hainbat ezaugarritan- ilokuzio-indarraren adierazle gisa jokatzen duela.
} 
Ilokuzio-indarraren adierazletzat jo ordez, pentsatuko bagenu esaldiaren proposizio-edukiari egiten diola ekarpena bidek, omenek nola (baina kasu honetan ezaugarri doxastikoa ekarriz), onartu beharko genuke Joanak, $S_{\text {bide }}$ ren esaldi bat egiten duenean, (37)ren edo (38)ren moduko zerbait baiesten duela.

(37) Uste dut oso litekeena dela euria aritzea gaur Anoetan, baina ez nago erabat ziur.

(38) Zeharkako ebidentzia dut euria ari duela gaur Anoetan.

Hau da, proposizio bat egiazkoa litzakeena baldin eta bakarrik baldin Joanak halako ustea balu ala halako ebidentzia balu, kontuan hartu gabe euria ari ote duen gaur Anoetan edo ez. Uste dugu ez dela egokia pentsatzea $p_{\text {bide }}$ baiesten duela hiztunak, eta ez $p$. Hain zuzen, egun jakin batean Anoetan euria egiteak (edo ez egiteak) bihurtzen du Joanaren esaldia egiazko (ala faltsu). Hiztunak esaldiaren proposizio-edukian duen ustearen neurria soilik markatzen du bidek: Joanak uste badu euria ari duela gaur Anoetan, zintzoki mintzo da; baliteke uste okerra izatea, ordea, eta faltsua den zerbait baiestea euririk ari ez badu.

Ondorio horixe atera dugu orain arteko azterketatik. Nolanahi ere, sakonago ikusi beharra dago bide onetik goazen bide ilokuzio-indarraren adierazletzat hartuta, eta ez proposizio-edukiari ekarpena egiten dion gisan. Horretarako, ezinbestekoa da onartze/ez-onartzearen testari eta eragin-eremuaren printzipioari gertuagotik jarraitzea. Horretan, noski, lagungarri, eta ezinbestekoa, izango da hiztunei esperimentuak egitea, gure intuizioak eurenekin alderatzeko.

\section{Ondorioa eta aurrera begirakoak}

Lan hau bide partikularen semantika eta pragmatikarako lehenbiziko hurbiltzea besterik ez da, aurretik omeni buruz ateratako ondorioetan oinarrituta egindakoa. Ikusi dugu, nahiz eta antzekotasunak badituzten, bi desberdintasun garrantzitsu badituztela bederik:

- Omeni egotzi izan zaion elementu doxastikoa (ziurtasunik eza) pragmatikari dagokio - GCI bat da-; bideri lotzen zaion elementu doxastikoa (ziurtasun handia baina ez erabatekoa), berriz, semantikari —haren kodetutako esanahia da-.

- Omenek esaldiaren proposizio-edukiari egiten dio ekarpena; bide, aldiz, ilokuzio-indarraren adierazlea da, eta ez die ekarpenik egiten esaldiaren egibaldintzei.

Gure ondorioak atera ditugu (jatorrizko) euskal hiztun gisa ditugun intuizioetan oinarrituta eta omen, bide eta bestelako elementuen adibideak al- 
deratuz, Ereduzko Prosa Gaur datu-basea baliatuta. Aurrera begira esperimentuak egiteko asmoa dugu, omenekin abiatutako bideari jarraituz.

Hala ere, badira jorratzeko hainbat kontu. Hasteko, zehaztu gabe geratu da bideren alderdi doxastikoaren eta ebidentzialaren arteko harremana. Nolanahi ere, arazoa ez da, agian, erabakitzea nola kategorizatu behar dugun bide - prest gaude onartzeko gehienetan, beti ez bada, batera doazela bi alderdiak- Baliteke orokorragoa izatea kontua. Kontua, eta arazoa, da, gure iritzian, ez dagoela garbi teorikoki zer den ebidentzialitatea. Esaterako, hiztunari $p$ proposizio jakin batentzako $0,2 \mathrm{ko}$ ziurtasun-neurria ematen dion zeharkako «ebidentzia» edo «froga» bat prentzako ebidentzia al da? Garbi hitz eginez gero, ezetz esango genuke. Aitzitik, ez-prentzako ebidentzia litzateke. Kontu ezberdina dirudi pren egiari eusteko ebidentziaren iturria zuzena edo zeharkakoa den, eta iturri horrek zenbaiteranoko ziurtasun-gradua eskaintzen duen. Horren erakusgarri da omen berri ematekoa: zeharkako hizkuntzazko informazio-iturria kodetzen du semantikoki, baina ez du ezer kodetzen ekarritako proposizioaz hiztunak duen ziurtasunari buruz.

Zeharkako ebidentziala, ebidentzial zuzena, doxastikoa edo epistemikoa, inferentziala, eta gisako terminoak teorikoki kategorizatzea findu egin beharra dago. Espero dugu hemengo eztabaidak bere ekarpentxoa egingo diola auziari. Bien bitartean, ea teorikoki argitzen dugun eta esperimentuen bidez probatu, eta ahal dela frogatu, omen eta bide partikulei eta horiei lotutako elementuei buruzko gure proposamen edo hurbiltze semantiko eta pragmatikoa.

\section{Erreferentzia bibliografikoak}

Alcázar, Asier (2009), «Subjectification in Basque evidential particles». Eskuizkribua.

Boye, Kasper (2010), «Semantic maps and the identification of cross-linguistic generic categories: Evidentiality and its relation to epistemic modality». Linguistic discovery 8-1: 4-22.

Boye, Kasper (2012), Epistemic meaning: A Crosslinguistic and Functional-Cognitive study. Berlin: Mouton de Gruyter.

Chafe, Wallace (1986), «Evidentiality in English conversation and academic Writing». In Wallace Chafe \& Johanna Nichols (arg.), Evidentiality: The Linguistic Coding of Epistemology. Volume XX in the Series Advances in Discourse Processes. Norwood, New Jersey: Ablex Publishing Corporation Norwood, NJ: Ablex, 261-272 or.

Cornillie, Bert (2009), «Evidentiality and epistemic modality. On the close relationship between two different categories». Functions of Language 16-1: 44-62.

Elhuyar-Elkar (1994), Euskal hiztegi modernoa. Donostia: Elhuyar-Elkar.

Euskaltzaindia (1987), Euskal Gramatika. Lehen Urratsak II. Bilbao.

Faller, Martina (2002), Semantics and Pragmatics of Evidentials in Cuzco Quechua. Doktoretza-tesia, Stanford University.

Faller, Martina (2006), «Evidentiality below and above speech acts». Manchester: University of Manchester, eskuizkribua. Sarean: http://personalpages.manchester. ac.uk/staff/martina.t.faller/documents/Evidentiality.Above.Below.pdf. 
Faller, Martina (2012), «Evidential scalar implicatures». Linguistics and Philosophy 35: 285-312.

Grice, Paul (1961), «The causal theory of perception». Proceedings of the Aristotelian Society, Supplementary volumes 35: 121-152.

Grice, Paul (1967a), «Logic and conversation». In Donald Davidson \& Gilbert Harman (arg.) (1975), The logic of grammar, Encino: Dickenson, 64-75 or. Peter Cole \& Jerry L. Morgan (arg.) (1975)-n argitaratua, baita ere, Syntax and semantics 3: Speech acts, New York: Academic Press, 41-58 or. Paul Grice (1989)-n berrargitaratua, Studies in the way of words, Cambridge (MA): Harvard University Press, 22-40 or.

Grice, Paul (1967b), «Further Notes on Logic and Conversation». In Peter Cole (arg.) (1978), Syntax and semantics 9: Pragmatics, New York: Academic Press, 113-128 or. Paul Grice (1989)-n berrargitaratua, Studies in the way of words, Cambridge (MA): Harvard University Press, 41-57.

Jendraschek, Gerd (2003), La Modalité Épistémique en Basque. Muenchen: Lincom Europa.

Korta, Kepa \& Larraitz Zubeldia (2014), «The contribution of evidentials to utterance content: Evidence from the Basque reportative particle omen». Language 90-2: 389423.

Korta, Kepa \& Larraitz Zubeldia (2015), «The evidential and doxastic dimensions of bide». Belgian Journal of Linguistics 29, ale berezia, J. Marín-Arrese \& B. Cornillie (arg.), On the Pragmatics Semantics interface of evidentiality, 41-59. doi 10.1075/ bj1.29.02kor.

Levinson, Stephen C. (1983), Pragmatics. Cambridge University Press.

Levinson, Stephen C. (2000), Presumptive Meanings. The Theory of Generalized Conversational Implicature. Cambridge, London: MIT Press.

Marín-Arrese, Juana I. (2015), «Epistemicity and stance: A crosslinguistic study of epistemic stance strategies in journalistic discourse in English and Spanish». Discourse Studies 17-2: 210-225.

Matlock, Teenie (1989), «Metaphor and the grammaticalization of evidentials». Proceedings of the Fifteenth Annual Meeting of the Berkeley Linguistics Society 15: 215-225.

Matthewson, Lisa (2012): «Evidence about evidentials: Where fieldwork meets theory». In Britta Stolterfoht \& Sam Featherston (arg.), Empirical approaches to linguistic theory: Studies in meaning and structure. Berlin: De Gruyter Mouton, 85114 or.

Matthewson, Lisa; Henry Davis \& Hotze Rullmann (2007), «Evidentials as epistemic modals: Evidence from St'át'imcets». Linguistic Variation Yearbook 7: 201-54.

McCready, Eric \& Norry Ogata (2007), «Evidentiality, modality and probability». Linguistics and Philosophy 30: 147-206.

Morris, Mikel (1998), Morris student plus. Euskara-ingelesa, english-basque. Donostia: Klaudio Harluxet Fundazioa. http://www1.euskadi.net/morris/

Murray, Sarah (2010), Evidentiality and the structure of speech acts. New Brunswick, NJ: Rutgers University dissertation.

Novia de Salcedo, Pedro (1887), Diccionario Etimológico del Idioma Bascongado. Tolosa: Eusebio López.

Orpustan, Jean-Baptiste (1993), Oihenarten Hiztegia. Lexique Basque des Proverbes et Poésies d'Oyhenart Traduit en Français et Espagnol / par Jean-Baptiste Orpustan. Baigorri: Izpegi.

Rijk, Rudolf P. G. de (2008), Standard Basque: a Progressive Grammar. Vol. 1: The grammar. Cambridge (Massachusetts): MIT Press. 
Sauerland, Uli \& Mathias Schenner (2007), «Shifting evidentials in Bulgarian». Proceedings of Sinn und Bedeutung 11: 525-539.

Schenner, Mathias (2008), «Double face evidentials in German: Reportative sollen and wollen in embedded contexts». In Atle Grønn (arg.), Proceedings of SuB12. Oslo: University of Oslo, 552-566 or.

Searle, John \& Daniel Vanderveken (1985), Foundations of illocutionary logic. Cambridge: Cambridge University Press.

van der Auwera, Johan \& Vladimir A. Plungian (1998), «Modality's semantic map». Linguistic typology 2: 79-123.

Vanderveken, Daniel (1990), Meaning and speech acts. Vol. 1. Principles of language use. Cambridge: Cambridge University Press.

van Eys, Willem J. (1873), Dictionnaire Basque-Français. Paris: Maisonneuve; London: Williams and Norgate.

Waldie, Ryan, Tyler Peterson, Hotze Rullmann \& Scott Mackie (2009), «Evidentials as epistemic modals or speech act operators: Testing the tests». Paper presented at the Workshop on the Structure and Constituency of Languages of the Americas 14 , Purdue University.

Wiemer, Björn \& Veronika Kampf (2012), «On conditions instantiating tip effects of epistemic and evidential meanings in Bulgarian». Slovene 2: 5-38.

Wiemer, Björn \& Anna Socka (2010), «How to do contrastive semantics with propositional modifiers: The case of hearsay adverbs». «Re-thinking synonymy: semantic sameness and similarity in languages and their description» symposiumean aurkeztutako lana (Helsinki).

Willett, Thomas (1988), «A cross-linguistic survey of the grammaticization of evidentiality». Studies in language 12: 51-97.

Zubeldia, Larraitz (2013), «(Non-)determining the original speaker: reportative particles versus reportative verbs». Research in Language 11-2: 103-130.

Zubeldia, Larraitz (2015), «Omen» partikularen azterketa semantikoa eta pragmatikoa. Bilbo: UEU. [2010ean aurkeztua]

\section{Corpusa}

Basque Institute of UPV/EHU, Ereduzko Prosa Gaur [Contemporary Reference Prose]: http://www.ehu.es/euskara-orria/euskara/ereduzkoa/

Iturriaga, Unai (1999), Berandu da gelditzeko. Zarautz; Iruñea: Susa.

Jimenez, Edorta (2003), Hemingway eta euskaldunak zerbitzu sekretuetan. Zarautz: Susa. Jimenez, Edorta (2004), Sukar ustelaren urtea. Tafalla: Txapalarta.

Mendiguren Elizegi, Xabier (2002), 16 ipuin amodiozko. Zarautz: Susa.

Sartre, Jean-Paul (1938), La nausée. Paris: Editions Gallimard. (Itzulpena: Monika Etxebarria, 2003, Goragalea. Donostia: Alberdania-Elkar). 
